\title{
A study on feto-maternal outcome in patients with premature rupture of membranes
}

\author{
Tripti Nagaria, Chandrakant Diwan*, Jyoti Jaiswal
}

Department of Obstetrics and Gynaecology, Pt. J. N. M. Medical College, Raipur, Chhattisgarh, India

Received: 10 November 2016

Accepted: 18 November 2016

\section{*Correspondence:}

Dr. Chandrakant Diwan,

E-mail: diwan1185@gmail.com

Copyright: () the author(s), publisher and licensee Medip Academy. This is an open-access article distributed under the terms of the Creative Commons Attribution Non-Commercial License, which permits unrestricted non-commercial use, distribution, and reproduction in any medium, provided the original work is properly cited.

\begin{abstract}
Background: Premature rupture of membranes (PROM) refers to a patient who is beyond 37 weeks' gestation and has presented with rupture of membranes (ROM) prior to the onset of labor. Patient with PROM presents with leakage of fluid, vaginal discharge and pelvic pressure, but they are not having contraction. It occurs in 3 percent of pregnancies and is the cause of approximately one third of preterm deliveries. It can lead to significant perinatal morbidity, including respiratory distress syndrome, neonatal sepsis, umbilical cord prolapse, placental abruption, and fetal death. Appropriate evaluation and management are important for improving neonatal outcomes. The risk of intrauterine infection increases with the duration of ROM. Evidence supports the idea that induction of labor, as opposed to expectant management, decreases the risk of chorioamnionitis without increasing the cesarean delivery rate.

Methods: The present prospective study was conducted in the Department of Obstetrics and Gynecology and associated Dr. B.R.A.M. Hospital Raipur (C.G.), India from January to December 2013 among the patients diagnosed as premature rupture of membrane with women complain of leaking attending antenatal OPD and antenatal ward. On admission detailed history was taken. General and Systemic examination were done including Per Abdomen, Per Speculum and per vaginum carried out and investigations were done as per protocol. Diagnosis of PROM was confirmed by any of this method. Continuous monitoring of maternal and fetal condition done, antibiotics was given intra/ post natal period. P/ V exam were done when necessary. Investigations done and maternal and fetal outcome were noted.

Results: More number of unbooked cases was found in study group in comparison to control group. Maximum women were in the age group of 20-25 years. Majority of cases in both the groups had pregnancy more than 36 weeks. PROM results in oligohydramnios due to drainage of liquor amnii. Majorities of the babies were underweight among mothers with PROM. Thus the better fetal outcome was associated with term gestational age. Higher chances of maternal complication were found among mothers with PROM.

Conclusions: From the above study, it can be concluded that PROM is associated with poor fetomaternal outcome. Early diagnosis and prompt management is required for better outcome of mother and baby.
\end{abstract}

Keywords: Fetomaternal Outcome, Morbidity, PROM, Pregnancy

\section{INTRODUCTION}

Premature rupture of membranes (PROM) refers to a patient who is beyond 37 weeks' gestation and has presented with rupture of membranes (ROM) prior to the onset of labor. Preterm premature rupture of membranes
(PPROM) is ROM prior to 37 weeks' gestation. Spontaneous premature rupture of the membranes (SPROM) is ROM after or with the onset of labor. Prolonged ROM is any ROM that persists for more than 24 hours and prior to the onset of labor PROM occurs in approximately $10 \%$ of pregnancy. Patient with PROM 
presents with leakage of fluid, vaginal discharge and pelvic pressure, but they are not having contraction. It occurs in 3 percent of pregnancies and is the cause of approximately one third of preterm deliveries. It can lead to significant perinatal morbidity, including respiratory distress syndrome, neonatal sepsis, umbilical cord prolapse, placental abruption, and fetal death. Appropriate evaluation and management are important for improving neonatal outcomes. ${ }^{1,2}$

At term, programmed cell death and activation of catabolic enzymes, such as collagenase and mechanical forces, result in ruptured membranes. Preterm PROM occurs probably due to the same mechanisms and premature activation of these pathways. However, early PROM also appears to be linked to underlying pathologic processes, most likely due to inflammation and/or infection of the membranes. Clinical factors associated with preterm PROM include low socioeconomic status, low body mass index, tobacco use, preterm labor history, urinary tract infection, vaginal bleeding at any time in pregnancy, circlage, and amniocentesis.

Most patients (90\%) enter spontaneous labour within 24 hours when they experience ROM at term. Eighty-five percent of neonatal morbidity and mortality is a result of prematurity. PPROM is associated with $30-40 \%$ of preterm deliveries and is the leading identifiable cause of preterm delivery. The major question regarding management of these patients is whether to allow them to enter labor spontaneously or to induce labor. In large part, the management of these patients depends on their desires; however, the major maternal risk at this gestational age is intrauterine infection. The risk of intrauterine infection increases with the duration of ROM. Evidence supports the idea that induction of labor, as opposed to expectant management, decreases the risk of chorioamnionitis without increasing the cesarean delivery rate. ${ }^{3-5}$

With this background, the present study was conducted to evaluate the fetomaternal outcome in cases of PROM and to compare with controls.

\section{METHODS}

The present prospective study was conducted in the Department of Obstetrics and Gynecology, associated Dr. B.R.A.M. Hospital Raipur (C.G.), India from January to December 2013 among the patients diagnosed as premature rupture of membrane with women complain of leaking attending antenatal OPD and antenatal ward. This study was approved by ethical and scientific committee. All 1000 patients of PROM at term were studied and matched against 1000 suitable controls of women during the same period according to predesigned proforma.

\section{Exclusion criteria}

Bleeding $\mathrm{p} / \mathrm{v}$, intact membrane. Less than 28 weeks of gestational age any complication of pregnancy other than PROM that affect fetal and neonatal outcome e.g. IUGR, foetal malformation, preeclampsia Cases with multiple gestation APH and parathyroid and adrenal diseases, hepatic and renal failure DM type 1, Malabsorption.

On admission detailed history was taken, in whom LMP not known gestational age confirmed by USG. Menstrual and obstetric, personal, past and family history were taken. General and Systemic examination were done including Per Abdomen, Per Speculum and per vaginum carried out and investigations were done as per protocol. Diagnosis of PROM was confirmed by any of this method. Leaking was demonstrated by P/S examination, $\mathrm{pH}$ test and fern test. On admission $\mathrm{P} / \mathrm{V}$ done and Bishop's Scoring done and correlated with duration of PROM to decide management like induction. Continuous monitoring of maternal and fetal condition done, antibiotics was given intra/ post natal period. P/ V exam were done when necessary. Cases and controls were followed as per protocol. Investigations done and maternal and fetal outcome were noted. Statistical analyses were performed through MS-excel. All categorical data were reported as number and percent.

\section{RESULTS}

Table 1: Distribution of cases according to booking status.

\begin{tabular}{|lllll|}
\hline \multirow{2}{*}{ Booking status } & \multicolumn{2}{c|}{ Study Group } & \multicolumn{2}{c|}{ Control Group } \\
\cline { 2 - 5 } & No & \% & No & \% \\
\hline Booked & 307 & 30.7 & 582 & 58.2 \\
\hline Un-booked & 693 & 69.3 & 418 & 41.8 \\
\hline Total & 1000 & $100 \%$ & 1000 & $100 \%$ \\
\hline
\end{tabular}

More number of unbooked cases was found in study group in comparison to control group. Maximum women were in the age group of 20-25 years (Table 1 and Table 2).

Table 2: Distribution of cases according to age in years.

\begin{tabular}{|lllll|}
\hline Age group in & \multicolumn{2}{l}{ Study } & Group & \multicolumn{2}{l|}{ Control Group } \\
years & No & \% & No & $\%$ \\
\hline$<20$ & 170 & 17 & 194 & 19.4 \\
\hline $20-25$ & 571 & 57.1 & 580 & 58 \\
\hline$>25-30$ & 223 & 22.3 & 203 & 20.3 \\
\hline$>30-35$ & 32 & 3.2 & 18 & 1.8 \\
\hline$>35-40$ & 4 & 0.4 & 5 & 0.5 \\
\hline Total & 1000 & $100 \%$ & 1000 & $100 \%$ \\
\hline
\end{tabular}

\section{Inclusion criteria}

All confirmed cases of PROM - more than 28 week. 
Table 3: Distribution of cases according to gestational age.

\begin{tabular}{|c|c|c|c|c|c|}
\hline \multirow{2}{*}{$\begin{array}{l}\text { Gestational } \\
\text { age in } \\
\text { weeks }\end{array}$} & \multicolumn{2}{|c|}{ Study group } & \multirow{2}{*}{$\begin{array}{l}\text { Control } \\
\text { No }\end{array}$} & \multirow{2}{*}{$\begin{array}{l}\text { group } \\
\%\end{array}$} & \multirow{2}{*}{$\begin{array}{l}\text { Chi value, } \\
\text { df, p value }\end{array}$} \\
\hline & No & $\%$ & & & \\
\hline $28-32$ & 61 & 6.1 & 26 & 2.6 & \multirow{5}{*}{$\begin{array}{l}16.938,3, \\
p<0.001 \\
{[\text { Significant }]}\end{array}$} \\
\hline$>32-37$ & 232 & 23.2 & 231 & 23.1 & \\
\hline$>37-40$ & 664 & 66.4 & 710 & 71 & \\
\hline$>40$ & 43 & 4.3 & 33 & 3.3 & \\
\hline Total & 1000 & $100 \%$ & 1000 & $100 \%$ & \\
\hline
\end{tabular}

Table 4: Distribution according to mode of delivery.

\begin{tabular}{|c|c|c|c|c|c|}
\hline \multirow{2}{*}{$\begin{array}{l}\text { Mode of } \\
\text { Delivery }\end{array}$} & \multicolumn{2}{|c|}{ Study group } & \multicolumn{2}{|c|}{$\begin{array}{l}\text { Control } \\
\text { group }\end{array}$} & \multirow{2}{*}{$\begin{array}{l}\text { Chi Value, } \\
\text { df, p value }\end{array}$} \\
\hline & No & $\%$ & No & $\%$ & \\
\hline Vaginal & 680 & 68 & 866 & 86.6 & \multirow{3}{*}{$\begin{array}{l}98.6,1, \\
<0.001 \\
\text { [Significant] }\end{array}$} \\
\hline LSCS & 320 & 32 & 134 & 13.4 & \\
\hline Total & 1000 & $100 \%$ & 1000 & $100 \%$ & \\
\hline
\end{tabular}

Majority of cases in both the groups had pregnancy more than 37 weeks. 68\% cases in study group and 86.6\% cases in control group had vaginal delivery.

Percentage of LSCS was more among study group and compared to control. Maximum cases (91.04\%) 783/860 delivered within $18 \mathrm{hrs}$ of induction (Table $3,4,5$ ).

Table 5: Distribution of according to induction delivery interval in hours.

\begin{tabular}{|lll|}
\hline $\begin{array}{l}\text { Induction delivery } \\
\text { (Interval in hours) }\end{array}$ & No. of cases & \\
\hline$<6 \mathrm{hrs}$ & $(\mathrm{n}=146)$ & $\%$ \\
\hline$>6-12 \mathrm{hrs}$ & $(\mathrm{n}=284)$ & $(17 \%)$ \\
\hline$>12-18 \mathrm{hrs}$ & $(\mathrm{n}=353)$ & $(41 \%)$ \\
\hline$>18-24 \mathrm{hrs}$ & $(\mathrm{n}=77)$ & $(9 \%)$ \\
\hline Mean IDI $=10.6 \mathrm{HRS}$ & Total=860 & \\
\hline
\end{tabular}

Table 6: Distribution of cases according to amniotic fluid index.

\begin{tabular}{|c|c|c|c|c|c|}
\hline \multirow{2}{*}{ USG Parameters AFI } & \multicolumn{2}{|c|}{ Study group } & \multicolumn{2}{|c|}{ Control group } & \multirow{2}{*}{ Chi value, df, $p$ value } \\
\hline & No & $\%$ & No & $0.6 \%$ & \\
\hline$<5 \mathrm{~cm}$ & 583 & $58.3 \%$ & 44 & $4.4 \%$ & \multirow{4}{*}{$\begin{array}{l}282.05,2,<0.001 \\
{[\text { Significant] }}\end{array}$} \\
\hline $5-10 \mathrm{~cm}$ & 417 & $41.7 \%$ & 560 & $56 \%$ & \\
\hline Adequate $>10 \mathrm{~cm}$ & 0 & 0 & 396 & $39.6 \%$ & \\
\hline Total & 1000 & $100 \%$ & 1000 & $100 \%$ & \\
\hline
\end{tabular}

Table 7: Distribution of cases according to baby weight.

\begin{tabular}{|c|c|c|c|c|c|}
\hline \multirow[t]{2}{*}{$\begin{array}{l}\text { Baby } \\
\text { weight } \\
\text { in kg }\end{array}$} & \multicolumn{2}{|c|}{ Study group } & \multicolumn{2}{|c|}{$\begin{array}{l}\text { Control } \\
\text { group }\end{array}$} & \multirow[t]{2}{*}{$\begin{array}{l}\text { Chi value, } \\
\text { df, p value }\end{array}$} \\
\hline & No & $\%$ & No & $\%$ & \\
\hline$<2 \mathrm{Kg}$ & 183 & $18.3 \%$ & 90 & $0.9 \%$ & \multirow{5}{*}{$\begin{array}{l}119.623,3, \\
<0.001 \\
{[\text { Significant }]}\end{array}$} \\
\hline $2-2.5 \mathrm{~kg}$ & 302 & $30.2 \%$ & 192 & $19.2 \%$ & \\
\hline $\begin{array}{l}>2.5- \\
3 \mathrm{~kg}\end{array}$ & 461 & $46.1 \%$ & 555 & $55.5 \%$ & \\
\hline$>3 \mathrm{~kg}$ & 54 & $5.4 \%$ & 163 & $16.3 \%$ & \\
\hline Total & 1000 & $100 \%$ & 1000 & $100 \%$ & \\
\hline
\end{tabular}

PROM results in oligohydramnios due to drainage of liquor amnii. Majorities of the babies were underweight among mothers with PROM.

The association between gestational age and APGAR score was found significant in relation to mode of delivery.

Thus the better fetal outcome was associated with term gestational age. Higher chances of maternal complication were found among mothers with PROM (Table 6, 7, 8, 9, and 10).

Table 8: Foetal outcome according to gestational AGL in LSCS.

\begin{tabular}{|c|c|c|c|c|c|c|c|}
\hline \multirow{2}{*}{ Gestational age } & \multicolumn{6}{|c|}{ APGAR score } & \multirow{2}{*}{ Chi value, df, p value } \\
\hline & 0-3 & $\%$ & $4-7$ & $\%$ & $8-10$ & $\%$ & \\
\hline$<37$ weeks $(\mathrm{N}=126)$ & 20 & 15.87 & 40 & 31.75 & 66 & 52.38 & \multirow{2}{*}{$\begin{array}{l}52.22,2,0.001 \\
\text { [Significant] }\end{array}$} \\
\hline$>37$ weeks $(\mathrm{N}=194)$ & 3 & 1.55 & 21 & 10.83 & 170 & 87.63 & \\
\hline
\end{tabular}


Table 9: Foetal outcome according to gestational age in vaginal delivery.

\begin{tabular}{|c|c|c|c|c|c|c|c|}
\hline \multirow[t]{2}{*}{ Gestational age } & \multicolumn{6}{|c|}{ APGAR Score } & Chi value, $d f$, $p$ value \\
\hline & $0-3$ & $\%$ & 4-7 & $\%$ & 8-10 & $\%$ & \multirow{4}{*}{$\begin{array}{l}142.236,2, p>0.001 \\
\text { [Significant] }\end{array}$} \\
\hline$<37$ weeks $(\mathrm{N}=167)$ & 23 & 13.77 & 61 & 36.53 & 83 & 49.70 & \\
\hline$>37$ weeks $(\mathrm{N}=513)$ & 13 & 2.54 & 21 & 4.09 & 408 & 79.53 & \\
\hline Total $=680$ & 56 & & 161 & & 463 & & \\
\hline
\end{tabular}

Table 10: Maternal complication between study and control group.

\begin{tabular}{|lll|}
\hline $\begin{array}{l}\text { Maternal } \\
\text { complication }\end{array}$ & Study group & Control group \\
\hline Fever (344) & $250(72 \%)$ & $94(28 \%)$ \\
\hline Wound Gap (37) & $28(75.67 \%)$ & $9(24.33 \%)$ \\
\hline Sepsis (7) & $5(71.43 \%)$ & $2(28.57 \%)$ \\
\hline Total & $283(28.3 \%)$ & $105(10.5 \%)$ \\
\hline
\end{tabular}

\section{DISCUSSION}

There are many studies which cover different aspects of fetomaternal outcome in PROM cases. ${ }^{6-9} 69.3 \%$ cases in the study group were unbooked, $30.7 \%$ were booked. $58.2 \%$ cases in the control group were booked, $41.8 \%$ were unbooked. Whenever the patient is booked in any institution, then the patient is being monitored and most of complication may be detected earlier either by taking history or examination then proper care of the patient can be taken regarding the complication. Most of women never received antenatal care and were unbooked similar to other studies such as Shah M and Sandesara $\mathrm{P}$ observed that $76 \%$ in study group were unbooked and $24 \%$ were booked .Our study supports proper antenatal care ,early detection and prevention of obstetrics complication and can improve the fetomaternal outcome. $^{10}$

In the present study $57.1 \% \%$ cases that is $571 / 1000$ were between $20-25$ yrs age and $22.3 \%$ cases (223/1000) were between 25-30 yrs age so nearly more than three fourth cases that is $79.4 \%(794 / 1000)$ presented between 20 to 30 yrs of age. Nearly $17 \%$ cases that is (170/1000) cases were below 20 yrs of age and only $36 / 1000$ i.e. $3.6 \%$ only were above 30 years of age. This was found to be similar to the control group. Our findings were also supported by Shah $\mathrm{M}$ and Sandesara $\mathrm{P}$ in their study. Studies by Lieman JM et al and Chaudhuri S et al showed that mean maternal age for the study cohort was 24.7_5.8 years and $23.2 \pm 3.9$ respectively. ${ }^{10-12}$

Gestational age in majority of the study subjects were >36week in the current study. Adeniji AO, Atanda OA and Biswas $\mathrm{T}$ et al also revealed nearly similar type of findings in relation to gestational age. ${ }^{13,14}$

Rate of Spontaneous Vaginal delivery and caesarean section was $68 \%$ and $32 \%$ while LSCS was $13.4 \%$ in control group. Rate of LSCS were range from 8.3 to $56 \%$ whereas rate of Spontaneous Vaginal delivery 42.3 to $88 \%$ in many previous studies. ${ }^{15-17}$

In present study best fetal outcome in terms of High APGAR score was observed in majority cases, when LSCS was done earlier. Previous many studies have established definitive relationship between timing of LSCS with fetal outcome. ${ }^{18,19}$

Fever occurs in $72 \%$ cases as against in $28 \%$ cases in control group. $28(75.67 \%)$ cases of wound gap in cases of prom and $9(24.33 \%)$ cases in control group 5 (71.43\%) cases of sepsis in study group and $2(28.57 \%)$ cases in control group. Maximum no. of fever cases $25 \%$ (250/1000) in study 126 group as compare to control group $9.4 \%$ (94/1000). Morbidity (28.3\%) 283 cases out of 1000 in study group and (10.5\%) 105 out of 1000 in control group which was statistically significant. Many studies also revealed higher chances of maternal complication with PROM cases. ${ }^{20-22}$

\section{CONCLUSION}

From the above study, it can be concluded that PROM is associated with poor fetomaternal outcome. Early diagnosis and prompt management is required for better outcome of mother and baby. ANC cases should be educated regarding regular and timely antenatal check up. At earlier stages of gestation, conservative management with careful surveillance for infection and fetal distress is a rational approach to the problem, to achieve further in utero fetal maturation. The obstetrician and neonatologist should work as a team to ensure optimal care for mother and fetus.

\section{ACKNOWLEDGEMENT}

The authors are thankful to all the faculty and technical staff members of the Department of Obstetrics and Gynecology, Pt. JNM Medical College and Dr. BAMH hospital, Raipur (C.G.), India, for their immense cooperation and support during the entire study period.

Funding: No funding sources

Conflict of interest: None declared

Ethical approval: The study was approved by the Institutional Ethics Committee 


\section{REFERENCES}

1. Frenette $\mathrm{P}$, Dodds L, Armson BA, Jangaard K. Pretermprelabour rupture of membranes: effect of latency on neonatal and maternal outcomes J Obstet Gynaecol Can. 2013 Aug;35(8):710-7.

2. Acaia B, Crovetto F, Ossola MW, Nozza S, Baffero GM, Somigliana E, et al. Predictive factors for neonatal survival in women with periviable preterm rupture of the membranes. J Matern Fetal Neonatal Med. 2013 Nov;26(16):1628-34.

3. Yalınkaya A. Continuous amnioin fusion via an epidural catheter following spontaneous membrane rupture: J Turkish-German Gynecol Assoc. 2013;14:238-41.

4. Akyol D, Mungan T, Unsal A, Yuksel, K. Pre labour Rupture of the Membranes at Term- No advantage of Delaying Induction for 24 Hours. Australia and NZ Journal of Obstetrics and Gynecology. 1999;39(3):291-5.

5. Shah B, Nagar N, Nagar S. A comparative study of labour induction with intravaginal misoprostol versus intravenous oxytocin in premature rupture of membranes beyond 36 weeks gestation, International Journal of Medical Science and Public Health. 2013;2(3):632-5.

6. Dadvand P, Basagaña X, Figueras F, Martinez D, Beelen R, Cirach M, et al. Air pollution and preterm premature rupture of membranes: a spatiotemporal analysis, Am J Epidemiol. 2014 Jan 15;179(2):200-7.

7. Duff P, Huff RW, Gibbs R. Management of Premature ruptures of Membranes and Unfavorable Cervix in Term Pregnancy. Obstetrics and Gynecology. 1984;63(5):697-702.

8. Goya M, Bernabeu A, García N, Plata J, Gonzalez F, Merced C, et al. Premature rupture of membranes before 34 weeks managed expectantly: maternal and perinatal outcomes in singletons, J Matern Fetal Neonatal Med. 2013 Feb;26(3):290-3.

9. Perinat J, Grunebaum A. Reply to Management of pre labour rupture of membranes (PROM) at terml. Med. 2013;41(6):651-2.

10. Shah M, Sandesara P. Fetomaternal Outcome In Premature Rupture Of Membrane (PROM)- A Case Control Study, Gujarat Medical Journal. 2011;66:1.

11. Lieman JM. Preterm Premature Rupture of Membranes: Is There an Optimal Gestational Age for
Delivery? The American College of Obstetricians and Gynecologists. Obstet Gynecol. 2005;105:12-7.

12. Chaudhuri S. Premature rupture of membranes at term: immediate induction with PGE2 gel compared with delayed induction with oxytocin. J Obstet Gynecol India. 2006;56(3):224-9.

13. Adeniji AO, Atanda OA. Interventions and neonatal outcomes in patients with premature rupture of fetal membranes at and beyond 34 weeks gestational age at a tertiary health facility in Nigeria SDI Paper Template Version; 2012.

14. Biswas T, Das SK, Kundu S. Preterm Prelabour Rupture of Membranes at 34-37 Weeks 'Gestation: Intentional Delivery versus Expectant Management JMSCR. 2014;2(6):1348-57.

15. Bangal VB. Induction of labour versus expectant management for premature rupture of membranes at term. IJBR 2012;3(3):164-70.

16. Malik HZ, Khawaja NP, Zahid B, Rehman R. Sublingual versus Oral Misoprostol for Induction of Labour in Prelabour Rupture of Membranes at Term. Journal of the College of Physicians and Surgeons Pakistan 2010;20(4):242-5.

17. Kappy AK. Premature Rupture of Membranes: A conservative approach. American Journal of Obstetrics and Gynecology. 1979;134(6):655-61.

18. Wagner MV, Chin VP, Peters CJ, Drexler B, Newman LA. A Comparison of Early and Delayed Induction of Labor with Spontaneous Rupture of Membranes at Term. Obstetrics and Gynecology. 1989;74(1):93-7

19. Zamzami, Y. Prelabor Rupture of membranes at term in low-risk women: induce or wait? Achives of Gynecology and Obstetrics. 2005;6:1-5.

20. Fatima U, Naz M, Khan RR. Labour induction with oral misoprostol in pre labour rupture of membranes at term JUMDC, 2013;4(1).

21. Khashoggi TY. Outcome Of Pregnancies With Preterm Premature Rupture Of Membranes, Saudi Med J. 2004;25(12):1957-61.

22. Singhal S, Puri M, Gami N. An Analysis Of Factors Affecting The duration of latency period and its impact on neonatal outcome on patients with PPROM, Int J Infertility Fetal Med. 2012;3(3):87-91.

Cite this article as: Nagaria T, Diwan C, Jaiswal J. A study on feto-maternal outcome in patients with premature rupture of membranes. Int J Reprod Contracept Obstet Gynecol 2016;5:4123-7. 